\title{
Effect of Preconception Gamma Irradiation on Morphometric Assessment of Adult Female Mice and Embryo
}

\author{
Efecto de la Irradiación Gamma Preconcepción sobre la \\ Evaluación Morfométrica de Ratones Hembras Adultas y Embriones
}

Innocent A. Edagha*; Matthew T. Shokunbi**; Adeniyi A. Adenipekun ${ }^{* * v}$; Rosemary B. Bassey ${ }^{*}$ \& Moses B. Ekong*

EDAGHA, I. A.; SHOKUNBI, M. T.; ADENIPEKUN, A. A.; BASSEY, R. B. \& EKONG, M. B. Effect of preconception gamma irradiation on morphometric assessment of adult female mice and embryo. Int. J. Morphol., 31(2):594-599, 2013.

SUMMARY: The aim was to study the effect of preconception gamma irradiation on the gross morphometry of the adult female mice and its embryo. Twenty-seven mice; 18 females and 9 males: subdivided into 3 groups namely (Control, Non-Irradiation and Radiation) containing 6 females and 3 male mice each in 2:1 ratio. A gamma irradiation dose of $1 \mathrm{~Gy} / \mathrm{min}$ was delivered to each batch of mice exposed by a Cobalt 60, Theratron 780c model, by Atomic Energy of Canada Limited (AECL) at the Radiotherapy department of the University College Hospital, Ibadan. All the animals were mated 1 week post irradiation. Vaginal plugs were confirmed, and the pregnant females were sacrificed on day 14 of gestation by chloroform inhalation. The gross morphology of the female mice and their harvested litters were assessed and statistically analysed. A total of 113 embryos were harvested in all groups; 54 for Control, 50 for NonIrradiated and 9 for the irradiation group. The gross morphologic assessments of the fetuses were statistically significant at $\mathrm{P}$ value $<0.05$ for all the 3 groups compared. These findings suggest that a preconception irradiation affects the morphology of the female mice and its progeny.

KEY WORDS: Preconception; Irradiation; Gamma ray; Spinal cord; Embryo.

\section{INTRODUCTION}

Radiation is an example of a physical mutagenic agent. There are also many chemical agents as well as biological agents (such as viruses) that cause mutations (ECRR, 2010). The effect on the foetus of preconception $\mathrm{x}$-irradiation is less well described. Some studies in man show an increased incidence of chromosomal abnormalities in offspring of mothers who received preconception diagnostic x-rays (Wald, 1993). Other studies suggest an association between preconception paternal exposure to diagnostic x-rays and infant leukemia (Shu et al., 1994). Work in the past decade has increasingly suggested the potential importance of preconception paternal exposures to foetal growth and development. Mechanisms by which the father may contribute to birth outcomes include genetic and epigenetic phenomena (Olshan \& Faustman, 1993). A wide range of animal studies of internal irradiation have revealed profound developmental and offspring mortality effects which have not been addressed by ICRP (2003) or other risk agencies (ECRR, 2010).
Various biological endpoints of trans-generational effects have been analyzed in this connection and congenital malformations are one class of these endpoints (Nomura, 1982). Malformations can be mainly induced by ionizing radiation in mammals when the exposure takes place during organogenesis and it has been postulated that exposures during other phases of prenatal development do not cause such malformations (ICRP, 2003). However, it has been found that in certain mouse strains malformations can be induced by ionizing radiations as well as genotoxic substances when the exposures take place during preimplantation period (Streffer, 2006).

Apart from studies on mutation rates in somatic cells, considerable progress has also been made in the analysis of radiation-induced instability in the mammalian germ-line, where the effects of radiation exposure were investigated among offspring of irradiated parents. Trans-generational

\footnotetext{
* Department of Anatomy, Faculty of Basic Medical Sciences, College of Health Sciences, University of Uyo, Nigeria.

** Department of Anatomy, Faculty of Basic Medical Sciences, College of Health Sciences, University of Ibadan, Nigeria.

*** Department of Radiotherapy, University College Hospital Ibadan, Nigeria.
} 
studies have been designed to test the hypothesis that radiation-induced instability in the germ line of irradiated parents could be transmitted to the offspring and may, in turn, affect their mutation (Dubrova, 2003). It is now recognized that trans-generational genetic effects are mainly due to transmissible induced genetic instability (Natarajan, 2006).

\section{MATERIAL AND METHOD}

Experimental Animals. The animals were acclimatized for 3 weeks in the Animal holding room of the Department of Anatomy, College of Medicine, Ibadan. They were daily fed with mouse pellets and tap water was provided $\mathrm{ad}$ libitum.

Experimental Design. Twenty-seven mice that were used in the experiment were distributed as follows; 18 females and 9 males: Group A consisted of 3 male and 6 female mice that served as control. They were placed in two separate cages labelled A1 and A2 respectively. Group B consisted of 3 male mice exposed to gamma irradiation and 6 female mice not exposed to gamma irradiation. They were placed in two separate cages labelled B1 and B2 respectively. Group $\mathrm{C}$ consisted of 3 male and 6 female mice that were both exposed to gamma irradiation. They were placed in two separate cages labelled $\mathrm{C} 1$ and $\mathrm{C} 2$ respectively. Identification marks were placed on the mice using a red permanent marker for the purposes of distinguishing them in their individual cages.

Choice of Irradiation Dose. The choice of irradiation of $1 \mathrm{~Gy} / \mathrm{min}$ was arrived at, after review of similar experimental protocol (Malomo et al., 2005).

Irradiation Procedure. This procedure was carried out at the Radiotherapy department of the University College Hospital, Ibadan. The mice exposed to gamma irradiation were carefully anaesthetized with Ketamine intraperitoneally for mild unconsciousness at a dose of 0.02 $\mathrm{mg}$. The mice in a prone position were then gently strapped to a flat board and buckled. Four of these small boards were then arranged neatly together for exposure to gamma irradiation. The gonads of the mice were then irradiated with Cobalt 60, Theratron 780c model (manufactured by Atomic Energy of Canada Limited AECL), with an area of exposure being from the waist down (hemi-body). The Source Surface Distance (SSD) used was $80 \mathrm{~cm}$ i.e. distance between the source of the irradiation beam and the object irradiated, with the length $16 \mathrm{~cm}$, width $4 \mathrm{~cm}$ and depth $2 \mathrm{~cm}$.
Mating Procedures. This began one week post-irradiation. Each group consisting of 6 female mice and 3 males were mated at a ratio of $2: 1$.

The cages of the males and females were placed side by side in a dark room for 1 hour, after which the males were transferred into the female cages. The cages were left in a dark room for overnight. Vaginal plugs were subsequently examined early next morning. Female mice with vaginal plug were removed from their cages and transferred to another cage and recorded as day ' 0 ' of pregnancy.

\section{Measurement of Gross and Microscopic Parameters.} The weight of the embryos was measured using Metler analytical balance, crown rump length (CRL) using manual sliding callipers, bi-parietal index (BPI) using manual sliding callipers and fronto-occipital index (FOI) using manual sliding callipers.

Statistical Analysis. Data obtained was analyzed using Fisher's Exact T-test otherwise known as ANOVA through an SPSS 14 software package. Confidence interval was calculated at $95 \%$ level. The level of significance was fixed at less than $5 \%$.

\section{RESULTS}

During the course of the experiment the results and observations were categorized into two major headings; the gross observation and the measurement of gross morphologic parameters.

Gross observation within 24 hours after irradiation, reduced motor function and activity, breathing difficulties, excessive urination was observed; clustering of animals together in a corner of their cage, reduced feed and water intake was also observed. They laid down in a stretched prone position, looked drowsy and sleepy, pupil of the eye were dilated and less pinkish in colour, consciousness and agile activities resumed towards a 24 hour period, one death was recorded after 12 hours and a large tumour in one of the irradiated female mice 1 week post-irradiation (Fig. 1).

The body weights of all the female mice serving as control in the experiment were recorded and statistically compared with those exposed to irradiation on day 7 , that is, one week post-irradiation. The result obtained was statistically significant at a p value $<0.05$ for the control and irradiated groups, as well as among the non-irradiated and irradiated groups as shown in Table I. 
The body weights of all the female mice in the experiment were recorded for each group on day 14 post vaginal plug. The result showed that there was no statistical significance on their weight variation. This is presented in Table II.

A total of 113 pups were obtained at the end of the experiment. These consist of fifty-four for the control, fifty for the irradiated and non-irradiated female group, nine for the irradiated male and irradiated female group, as only one female was confirmed pregnant in this group.

Table I. Weight of adult female mice on day 7 post irradiation (g).

\begin{tabular}{lccc}
\hline Groups & $\mathrm{n}$ & Mean $($ SD) & p value \\
\hline Control & 10 & $23.9(0.8)$ & 1 \\
Non-Irradiated & 10 & $23.9(0.8)$ & \\
Control & 10 & $23.9(0.8)$ & $0.01^{*}$ \\
Irradiated & 9 & $22.7(0.8)$ & \\
Non-Irradiated & 10 & $23.9(0.8)$ & $0.01^{*}$ \\
Irradiated & 9 & $22.7(0.8)$ & \\
\hline
\end{tabular}

* Statistically significant at $\mathrm{P}<0.05$

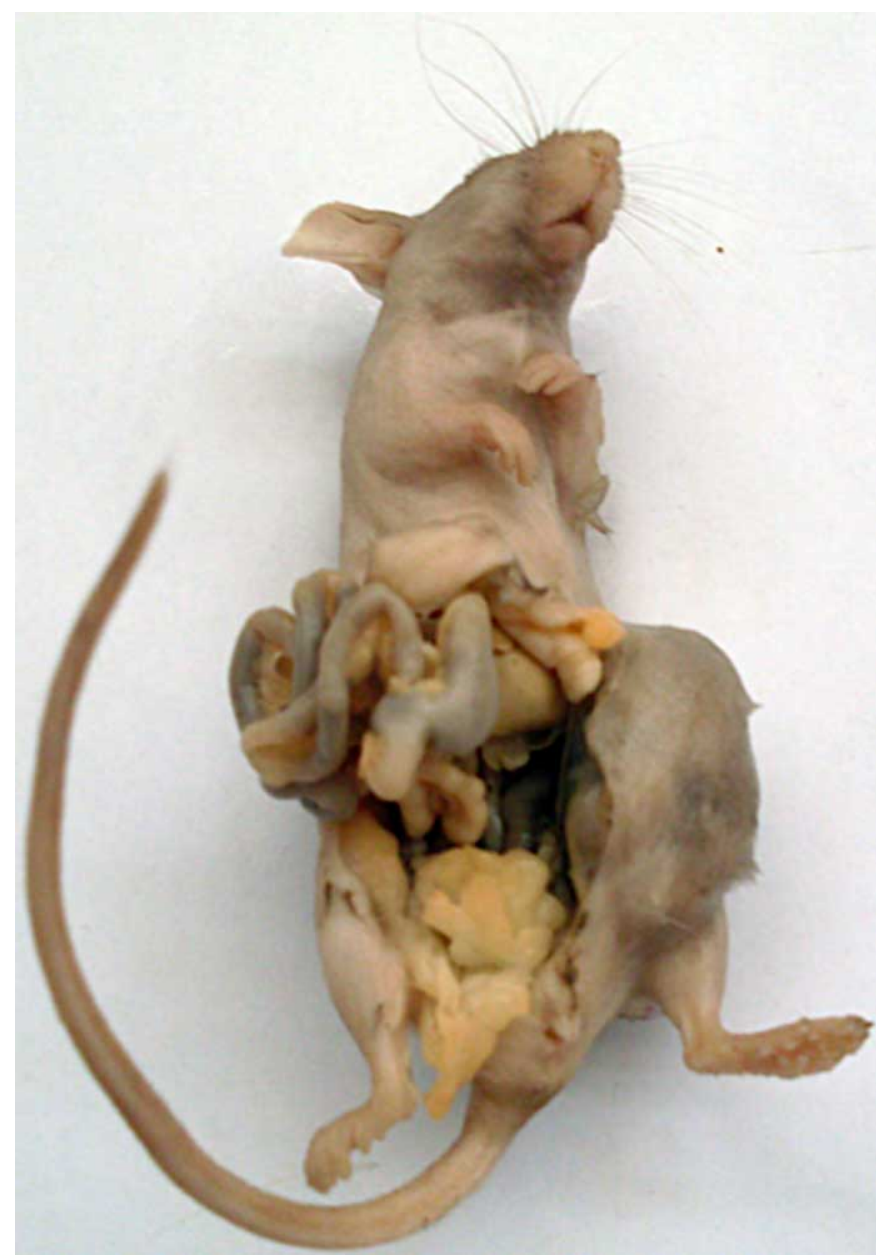

Fig. 1. A tumour beneath left hind limb of irradiated female mice.
The mean of the litter size of all the three groups namely the control, Irradiated male with Non-Irradiated female, and the Irradiated male with Irradiated female was not statistically significant at $P$ value of 0.05 . This is presented in Table III

Some morphological measurements of the litters were recorded in all the three groups (Fig. 2) and their statistical analysis showed that they were all significant as shown in Tables IV-VI.

Table II. Weights of adult pregnant mice on day 14 post vaginal plug.

\begin{tabular}{lccc}
\hline Groups & $\mathrm{n}$ & Mean $($ SD) & p value \\
\hline Control & 6 & $29.1(0.9)$ & 1 \\
Non-Irradiated & 6 & $28.6(0.8)$ & \\
Control & 6 & $29.1(0.9)$ & $0.01 *$ \\
Irradiated & 1 & $27.0(0.0)$ & \\
Non-Irradiated & 6 & $28.6(0.8)$ & $0.01 *$ \\
Irradiated & 1 & $27.0(0.0)$ & \\
\hline
\end{tabular}

* Statistically significant at $\mathrm{P}<0.05$

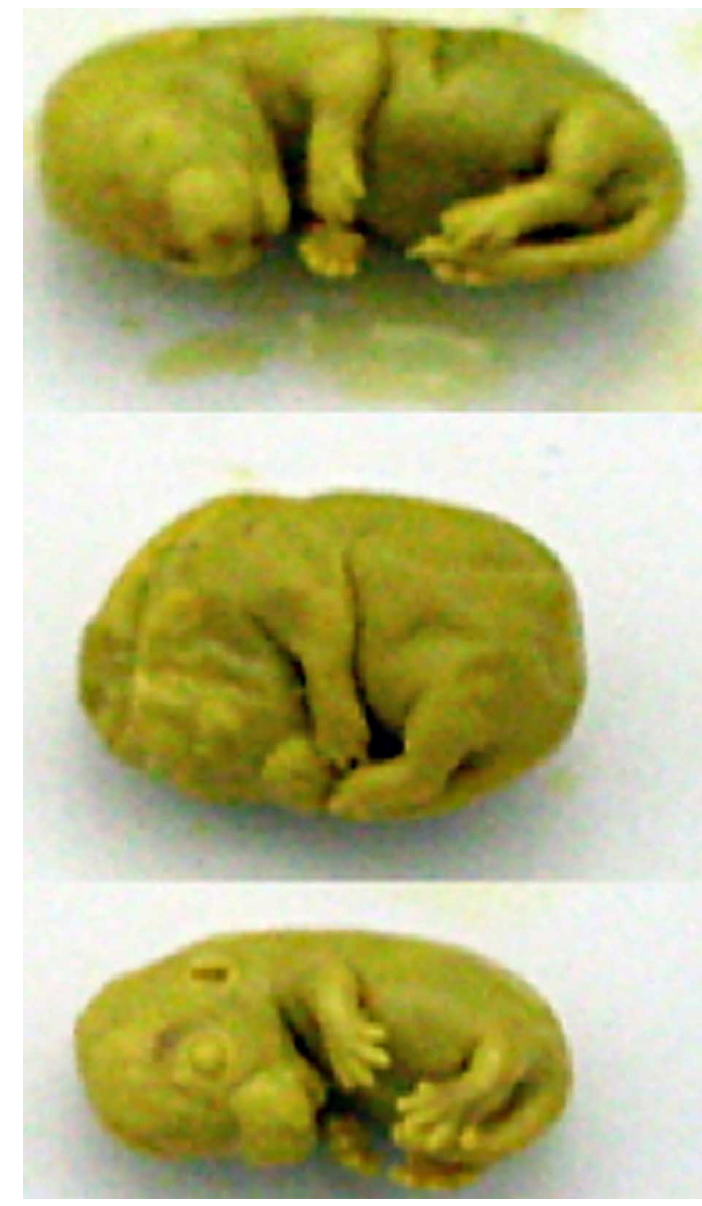

Fig. 2. Topmost - embryo from control. Middle - embryo from irradiated male mated with non-irradiated female. Lowest - embryo from irradiated male with irradiated female. 
Table II. Litter size.

\begin{tabular}{lccc}
\hline Groups & $\mathrm{n}$ & Mean (SD) & p value \\
\hline Control & 6 & $9.0(1.2)$ & 0.51 \\
Non-Irradiated & 6 & $8.3(0.8)$ & \\
Control & 6 & $9.0(1.2)$ & 1 \\
Irradiated & 1 & $9.0(0.8)$ & \\
Non-Irradiated & 6 & $8.3(2.0)$ & 0.77 \\
Irradiated & 1 & $9.0(0.0)$ & \\
* Statistically significant at $\mathrm{P}<0.05$. & &
\end{tabular}

Table IV. Gross morphologic assessment of foetuses in group 1 (day 14).

\begin{tabular}{llll}
\hline Gross Parameters & \multicolumn{1}{c}{ Groups $(\mathrm{n})$} & Mean $(\mathrm{SD})$ & p value \\
\hline \multirow{2}{*}{ Weight of litters $(\mathrm{g})$} & Control $(\mathrm{n}=10)$ & $0.41(0.03)$ & $0.001^{*}$ \\
& Non-Irradiated $(\mathrm{n}=10)$ & $0.23(0.02)$ & \\
Crown Rump Length $(\mathrm{CRL})(\mathrm{cm})$ & Control $(\mathrm{n}=10)$ & $1.23(0.04)$ & $0.001 *$ \\
& Non-Irradiated $(\mathrm{n}=10)$ & $1.02(0.07)$ & \\
Bi-parietal Index (BPI) $(\mathrm{cm})$ & Control $(\mathrm{n}=10)$ & $0.44(0.05)$ & $0.001 *$ \\
& Non-Irradiated $(\mathrm{n}=10)$ & $0.30(0.01)$ & \\
Fronto-occipital Index $(\mathrm{FOI})(\mathrm{cm})$ & Control $(\mathrm{n}=10)$ & $0.68(0.03)$ & $0.001 *$ \\
& Non-Irradiated $(\mathrm{n}=10)$ & $0.59(0.02)$ & \\
\hline * Statistically significant at $\mathrm{P}<0.05$ & & &
\end{tabular}

Table V. Gross morphologic assessment of foetuses in group 2 (day 14).

\begin{tabular}{llll}
\hline Gross Parameters & Groups $(\mathrm{n})$ & Mean $(\mathrm{SD})$ & p value \\
\hline \multirow{2}{*}{ Weight of litters $(\mathrm{g})$} & Control $(\mathrm{n}=10)$ & $0.41(0.03)$ & $0.001^{*}$ \\
& Irradiated $(\mathrm{n}=9)$ & $0.21(0.02)$ & \\
Crown Rump Length $(\mathrm{CRL})(\mathrm{cm})$ & Control $(\mathrm{n}=10)$ & $1.20(0.04)$ & $0.001^{*}$ \\
& Irradiated $(\mathrm{n}=9)$ & $0.90(0.11)$ & \\
Bi-parietal Index (BPI) $(\mathrm{cm})$ & Control $(\mathrm{n}=10)$ & $0.44(0.05)$ & $0.001 *$ \\
& Irradiated $(\mathrm{n}=9)$ & $0.24(0.15)$ & \\
Fronto-occipital Index $(\mathrm{FOI})(\mathrm{cm})$ & Control $(\mathrm{n}=10)$ & $0.68(0.03)$ & $0.001 *$ \\
\hline
\end{tabular}

* Statistically significant at $\mathrm{P}<0.05$.

Table VI. Gross morphologic assessment of fetuses in group 3 (day 14).

\begin{tabular}{|c|c|c|c|}
\hline Gross Parameters & Groups (n) & Mean (SD) & p value \\
\hline \multirow{2}{*}{ Weight of litters (g) } & Non-Irradiated $(n=10)$ & $0.23(0.02)$ & \multirow{2}{*}{$0.016^{*}$} \\
\hline & Irradiated $(n=9)$ & $0.21(0.01)$ & \\
\hline \multirow{2}{*}{ Crown Rump Length (CRL) (cm) } & Non-Irradiated $(n=10)$ & $1.02(0.07)$ & \multirow{2}{*}{$0.014^{*}$} \\
\hline & Irradiated $(n=9)$ & $0.90(0.11)$ & \\
\hline \multirow{2}{*}{ Bi-parietal Index (BPI) (cm) } & Non-Irradiated $(n=10)$ & $0.30(0.01)$ & \multirow{2}{*}{$0.004^{*}$} \\
\hline & Irradiated $(n=9)$ & $0.24(0.05)$ & \\
\hline \multirow{2}{*}{ Fronto-occipital Index (FOI) (cm) } & Non-Irradiated $(n=10)$ & $0.59(0.02)$ & \multirow{2}{*}{$0.001^{*}$} \\
\hline & Irradiated $(n=9)$ & $0.50(0.01)$ & \\
\hline
\end{tabular}

* Statistically significant at $\mathrm{P}<0.05$. 


\section{DISCUSSION}

According to Upton et al. (1992), the effects of exposure to low radiation doses may damage health after several years of exposure. Ionizing radiation is known to have detrimental effects on the reproductive systems of both males and females (Ladner et al., 1991). There are evidences of association between occupational exposure, cytogenetic alterations and the increase in cancer rates (Mitelman et al., 1997).

Parental exposure of mice to radiation and chemicals causes a variety of adverse effects (e.g., tumors, congenital malformations and embryonic deaths) in the progeny and tumor-susceptibility phenotype is transmissible beyond the first post-radiation generation (Nomura, 2006).

Since ionizing radiation is capable of inducing a wide spectrum of cellular, molecular, biochemical and hormonal abnormalities. The aim of the experiment was to study the morphology development and growth, in mice progeny mediated through the father.

In this study, we investigated the association between mice paternal gamma-ray exposure prior to coitus and conception, and the subsequent effect on the morphology of the mice progeny. The reported data from parental gonad gamma irradiation at $1 \mathrm{~Gy} / \mathrm{min}$ and subsequent mating at 1 week post-irradiation presented evidence of a significant effect on the fertility of the female mice with respect to their ability to conceive after mating, and even with the confirmation of a vaginal plug compared with the control and intermediate groups. This is also similar to results obtained by Streffer.

Although, a statistical significant value was not obtained for the litter size of the foetuses, this may be due to the fact that there was only one conception from a single female mouse in the Irradiation group when compared with the Control and Non-Irradiation groups which yielded foetuses from all the female mice. A gross observation indicates that the acute dose generated radiation sickness which led to a significant weight loss and mortality. This is consistent with several other findings (Malomo et al.; Nomura, 2006; Shea \& Little, 1997; Vorobsova, 2000).

Gross results in this study revealed that body weight of the control group compared to non-irradiated group was not statistically significant. The body weight of the control group compared to irradiation group at 7 days post irradiation was statistically significant. The body weight of the nonirradiated group compared with irradiation group was statistically significant.
The reason for this weight loss remains unknown but could be due to the fact that the animals ate less and were therefore less active. Increased catabolism may have resulted in weight loss. This could also be due to their response to trauma. The development of copious diarrhoea by all animals that were given irradiation is likely due to radiation sickness, inflammatory responses, and decreased absorption of water and nutrients of the continuously cycling cells of the gastrointestinal epithelium from scattered effect of irradiation. This leads to loss of water absorptive capacity of the simple columnar epithelial cells. The water loss may have been responsible for the weight loss (Malomo et al.).

Experimental studies on plants and animals suggest that such effects will occur, and that such effects will range from the undetectably trivial, through gross malformations and loss of function, to premature death. Since this statement was made, applications of the mini satellite DNA testing procedure have shown unambiguous evidence of such effect including mutation in the offspring of the Chernobyl 'liquidators' (ECRR).

\section{CONCLUSION}

Irradiation of hemi-body of locally bred adult mice (male and female) with $1 \mathrm{~Gy} /$ minute of gamma rays obtained from Cobalt 60 elicited systemic problems leading to radiation sickness which includes - excessive urination, reduced motor function and activity, breathing difficulties and change in coloration of the eye. Statistically significant weight loss in the irradiated mice at $\mathrm{P}<0.05$

Statistically significant effect on gross parameters from litters of experimental groups compared with the control group mice which include; weight, crown rump length (CRL), bi-parietal index (BPI), and fronto-occipital index (FOI).

Thus the reported data shows that a transgenerational transmission occurs for radiation induced instability in progeny of preconceptional gonadal gamma irradiated mice especially at their gross structure and were statistically significant for weight, CRL, BPI, and FOI of the litters.

ACKNOWLEDGEMENT. We acknowledge Mrs. Ekishola of Radiotherapy Department, University College Hospital, Ibadan. 
EDAGHA, I. A.; SHOKUNBI, M. T.; ADENIPEKUN, A. A.; BASSEY, R. B. \& EKONG, M. B. Efecto de la irradiación gamma preconcepción sobre la evaluación morfométrica de ratones hembras adultas y embriones. Int. J. Morphol., 31(2):594-599, 2013.

RESUMEN: El objetivo fue estudiar el efecto de la irradiación gamma antes de la concepción sobre la morfometría macroscópica de ratones hembra adultos y los embriones de sus crías. Veinte y siete ratones, 18 hembras y 9 machos, divididos en 3 grupos (control, sin irradiación e irradiado) con 6 hembras y 3 machos cada uno en proporción 2:1. Una dosis de radiación gamma de 1 Gy/min fue aplicada a uno de los ratones expuestos por un equipo Cobalt 60, Theratron modelo 780c, Atomic Energy of Canada Limited (AECL) en el departamento de radioterapia del Hospital University College de Ibadan. Todos los animales se aparearon 1 semana después de la irradiación. Se confirmaron los tapones vaginales, y las hembras preñadas fueron sacrificadas en el día 14 de la gestación por inhalación de cloroformo. La morfología general de los ratones hembras y sus camadas fueron evaluadas y analizadas estadísticamente. Un total de 113 embriones se recolectaron en todos los grupos, 54 del grupo control, 50 del grupo no irradiados y 9 del grupo irradiado. Las evaluaciones morfológicas macroscópicas de los fetos fueron estadísticamente significativas ( $p<0,05)$ para los 3 grupos de comparación. Estos hallazgos sugieren que una irradiación previa a la concepción afecta a la morfología de los ratones hembra y su progenie.

PALABRAS CLAVE: Preconcepción; Irradiación; Radiación Gamma; Médula espinal; Embrión.

\section{REFERENCES}

Dubrova, Y. E. Radiation-induced transgenerational instability. Oncogene, 22(45):7087-93, 2003.

ECRR. Recommendations of the European Committee on Radiation Risk. The Health Effects of Exposure to Low Doses of Ionizing Radiation. Brussels, Regulators' Edition, 2010. p.80.

ICRP. Biological Effects after Prenatal Irradiation (Embryo and Fetus). Publication 90, Annals of ICRP 33 (1-2). Oxford, Pergamon Press, 2003.

Ladner, H. A.; Schere, E.; Streffer, C. \& Trott, K. Reproductive organs. Radiopathology of organs and tissues. New York, Springer-Verlag, 1991. pp.433-59.

Malomo, A. O.; Owoeye, O.; Elumelu, T. N.; Akang, E. E.; Adenipekun, A.; Campbell, O. B.; et al. Effects of dexamethasone, metronidazole and ascorbic acid on morphological changes induced by gamma rays on the spinal cord of wistar rats. Afr. J. Med. Sci., 34(2):161-5, 2005.

Mitelman, F.; Mertens, F. \& Johansson, B. A breakpoint map of recurrent chromosomal rearrangements in human neoplasia. Nat. Genet., 15 Spec. No.:417-74, 1997.

Natarajan, A. T. Induced Transgenerational Genetic Effects in Rodents and Humans. J. Radiat. Res., 47 Suppl. B:B39-43, 2006.

Nomura, T. Parental exposure to x-rays and chemicals induces hereditable tumors and anomalies in mice. Nature, 296(5857):575-7, 1982.

Nomura, T. Trans-generational Effects of Radiation and Chemicals in Mice and Humans. J. Radiat. Res., 47 Suppl. B:B83-97, 2006.

Olshan, A. F. \& Faustman, E. M. Male-mediated developmental toxicity. Annu. Rev. Public Health, 14:159-81, 1993.
Shea, K. M. \& Little, R. E. Is There an Association between Preconception Paternal x-ray Exposure and Birth Outcome? Am. J. Epidemiol., 145(6):546-51, 1997.

Shu, X. O.; Reaman, G. H.; Lampkin, B.; Sather, H. N.; Pendergrass, T. W. \& Robison, L. L. Association of diagnostic x-ray exposure with risk of infant leukemia. Cancer Epidemiol. Biomarkers Prev., 3(8):645-53, 1994.

Streffer, C. Trans-generational Transmission of Radiation Damage: Genomic Instability and Congenital Malformation. J. Radiat. Res., 47 Suppl. B:B19-24, 2006.

Upton, A. C.; Shore, R. E. \& Harley, N. H. The health effects of low-level ionizing radiation. Annu. Rev. Public Health, 13:127$50,1992$.

Vorobsova, I. E. Irradiation of male rats increases the chromosomal sensitivity of progeny to genotoxic agents. Mutagenesis, 15(1):33-8, 2000.

Wald, N. Ionizing radiation: Case studies in environmental medicine. San Rafael, CA, US Department of Health and Human Services, Agency for Toxic Substances and Disease Registry, 1993. pp.14-5.

Correspondence to:

Innocent A. Edagha

Department of Anatomy, Faculty of Basic Medical Sciences

College of Health Sciences

University of Uyo

P.M.B. 1017, Uyo, Akwa Ibom State

NIGERIA

Email: iedagha@yahoo.com

Received: 02-01-2012

Accepted: 01-03-2013 